\title{
偏圧が作用する山留め架構の実測挙動とその解析 BEHAVIOR OF THE EARTH RETAINING STRUCTURES. ACTED UPON BY UNSYMMETRICAL LATERAL PRESSURE AND A METHOD OF ANALYZING THIS BEHAVIOR
}

\author{
宮 崎. 祐 助*, 風 間 了**, 村田淳也*** \\ Yusuke MIYAZAKI, Satoru KAZAMA and Junya MURATA.
}

\begin{abstract}
This report proposes an analytical method for earth retaining structures subjected to unsymmetrical lateral pressure during excavation.

The analytical method we propose is based on the beam-spring model whitch is widely used to design shoring. This method allows integrated calculation of the interaction of opposing retaining walls through the medium of the struts, taking account of the continuity condition of the shearing force in the strut positions.

This report includes a detailed description of this analytical method and the results of a veri. fication study conducted using an actual earth retaining structure subjected to unsymmetrical :" lateral pressure" during excavation.
\end{abstract}

Keywords : dracing, unsymmetrical lateral pressure, analysis, monitoring 山留め, 偏圧, 解析, 計測.

\section{1. まえがき}

山留め架構には, 山留めに隣接する構造物や上載荷重 あるいは地表面の高低差などによる種々の偏圧が作用す る。切梁工法で山留めをした場合，片方に作用する偏圧 は切梁を介して対面する山留め壁に作用することにな る。このように，山留め架構には，多くの場合，大小の 差はあるものの, 偏圧が作用すると考えてよい。一方, 偏圧が作用した山留め架構の挙動に関する事例, またそ の解析事例，さらに実用的設計法の提案は極めて少ない 現状にある。

筆者らは, 都下における根切り工事中に, 異常降雨に よって急増した水圧が偏圧として作用し, 山留め架構の 挙動が急変した事例を実測データより確認することがで きた。

そこで, 本研究では, まず,この偏圧作用時の山留め. 架構の実測挙動を異常降雨時の水圧上昇との関係で考察 した。次に, 同山留め架構の挙動解析を, 本論で提示す る対面する山留め壁の一体解析方法で行い，その実挙動 を解析值との対比により検討した。
2. 本論で対象にした工事場の地盤, 山留め架構および 計測の概要

上記工事場は，東京の杉並区荻窪地内で，地形的には 武蔵野段丘の武蔵野面に位置する。

地層構成は，以下のとおりである（図一1）。

本地盤の上層部には, 地表面加 ら, 層厚約 $3.5 \sim 5 \mathrm{~m}$ のローム層 $(N$ 値 $\doteqdot 3)$, 層厚約 $4.5 \mathrm{~m}$ のシルト混り砂 層 $(N \doteqdot 2 \sim 6)$, 層厚約 $2 \mathrm{~m}$ の粘土層 $(N$ 値 $=5)$, 層厚 約 $2.5 \mathrm{~m}$ の砂層 $(N$ 値 $=10)$ が堆積している。また, G. L. $-12.5 \sim 14.0 \mathrm{~m}$ 以深の下層部は, 層厚約 4.5 $5.5 \mathrm{~m}$ の砂啋層 $(N$ 值 $\doteqdot 35 \sim 50)$, 層厚約 2 $2 \mathrm{~m}$ の固 結シルト層 $(N$ 值 $\div 35 \sim 50)$, 層厚 $5 \sim 7 \mathrm{~m}$ の砂磁層 $(N$ 値 $\geqq 50 ）$ と続き, 以下調查深度 $31 \mathrm{~m}$ までの固結シルト 層（ $N$ 值 $=30 \sim 40 ） て ゙$ 構成されている。調查時点での 地下水位は G. L. $-5 \mathrm{~m}$ 前後であった。

山留め平面は, 図一 2 に示すように, 約 $49 \times 33 \mathrm{~m}$ の 事務所棟に, 約 $23 \times 21 \mathrm{~m}$ の駐輪場棟が隣接する形状亡 なっている。根切り深さは, それぞれ $17.8 \mathrm{~m}$ と $10.0 \mathrm{~m}$ で，駐輪場棟の根切りは，事務所棟の地下駆体完成後に
* (株) 大林組技術研究所 研究室長・修士 (工学)

** 早稲田大学理工学研究所 教授・博士 (工学)

*** 早稲田大学大学院理工学研究科 大学院生・学士 (工学)
Chief Research Engineer, Obayashi Corporation Technical Research Institute, M. Eng.

Prof., Science and Engineering Research Laboratory, Waseda Univ., Dr. Eng.

Graduate Student, Graduate School of Science and Engineering, Waseda Univ. 


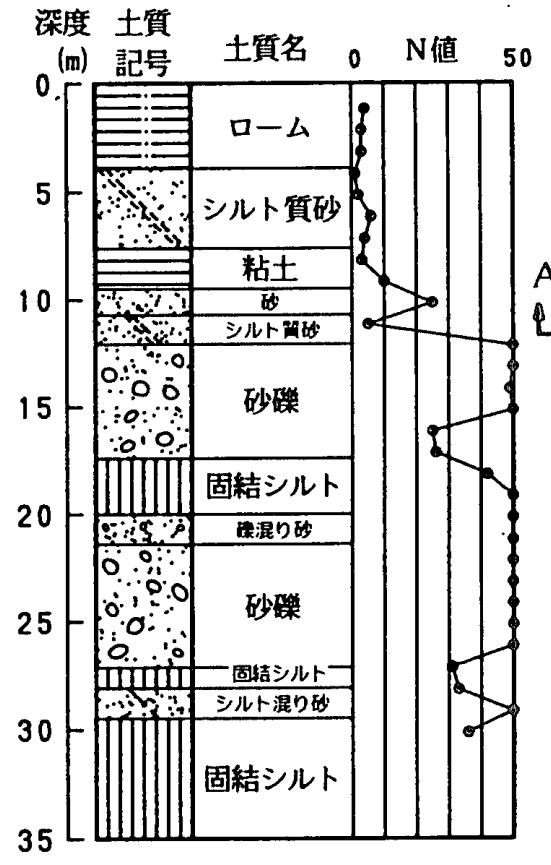

図一1 ボーリング柱状図

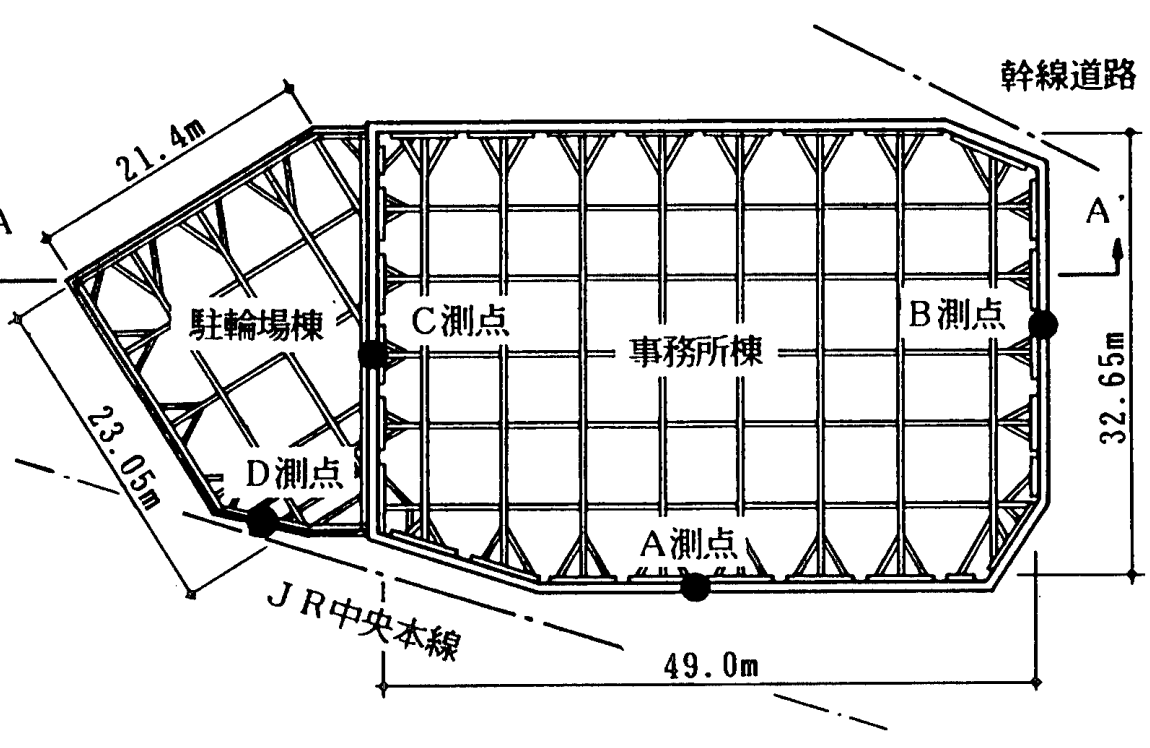

図一2 山留め平面図
駐輪場棟

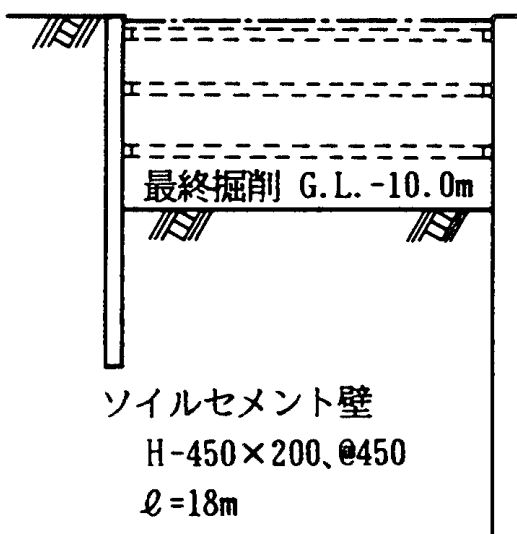

事務所棟

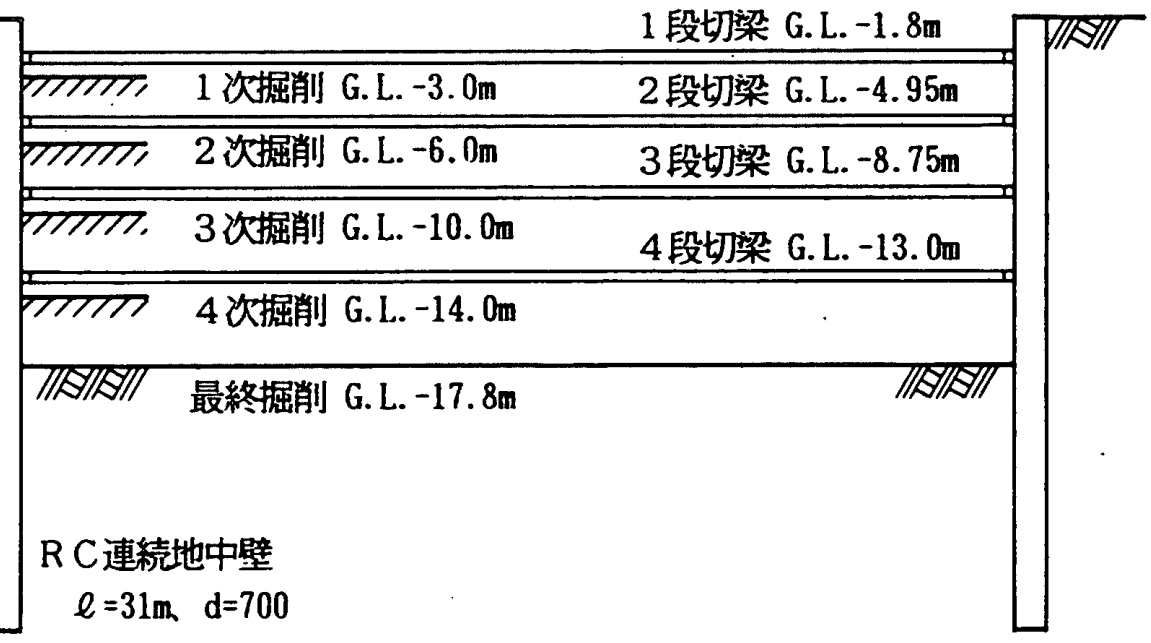

図一3 山留䉼面図 ( $A-A^{\prime}$ 断面)
行う計画となっていた。

山留め壁（図一3）には, 事務所棟で RC 地中壁（壁 厚： $700 \mathrm{~mm}$, 長さ：31 m) を, また駐輪場棟部ではソ イルセメント壁（壁厚：550 mm, 応力材 (芯材)： @ $450 \mathrm{~mm}, \mathrm{H}-450 \times 200 \times 9 \times 14$, 長さ $18 \mathrm{~m}$ ) を採用した。

工事場は，上述したように地盤状況も良く根切り工事 の難易度も高いものではないが, 敷地が JR 中央線と幹 線道路に接すること, また, 根切り深さとその時期が異 なる工区が存在することから, 事務所棟工区（根切り深 さ：17.8 m) では，安全を期して計測管理を導入した。 主要な計測項目を下記に，またその詳細を表一1および 図一2,4 に示した。

〈計測項目〉

(1) 山留め壁に作用する側圧と水王
(2) 山留め壁の鉄筋応力

(3) 山留め壁の変形

(4) 切梁軸力

(5) 周辺地盤の沈下

\section{3. 異常降雨時の水圧上昇と山留め壁の実測挙動}

平成 3 年 9 月, 本根切り工事中において, 異常降雨に よって急増した水王が片側の山留め壁に偏圧として作用 し, 対面する山留め架構全体が水圧作用方向に移動した。 そこで, 以下には, この偏圧 (水圧) 作用時の実測挙 動と異常降雨時の地下水位上昇との関係について考察す る。

3.1 異常降雨時の地下水位, 水圧

事務所棟工区の根切りは, 平成 3 年 6 月から着手し, 
表一1 測定項目および計器数量一覧

\begin{tabular}{|c|c|c|c|c|}
\hline 测 点 & 土圧計 & 水任計 & 鉄筋計 & 㨉入式傾斜計 \\
\hline A & 3 & 8 & 18 & 1 (30m) \\
\hline B & 3 & 8 & 18 & 1 (30ஐ) \\
\hline c & & & 27 & 1 (30m) \\
\hline $\mathrm{D}$ & & & & $1 \quad(18 m)$ \\
\hline 合 計 & 6 & 16 & 63 & $4(108 \pi)$ \\
\hline
\end{tabular}

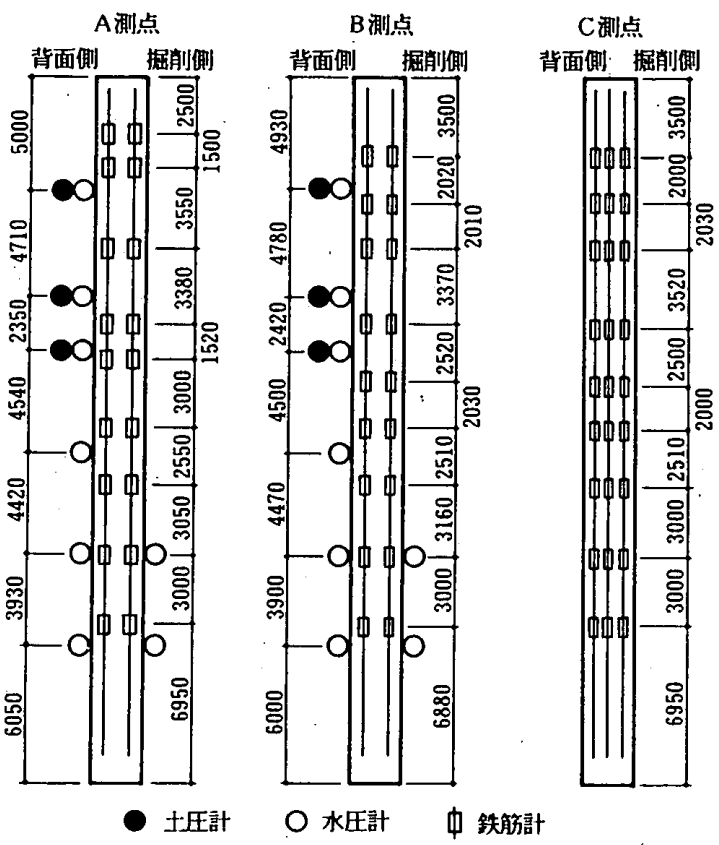

図一4 計測計器の配置

9 月中旬には， G. L. $-14 \mathrm{~m}$ までの 4 次根切りがほぼ終 了していた。この時期の，厳密にいえば，9月19日の 実測デー夕に，事務所棟工区と駐輪場棟工区との境界と なる山留時 (測点 C) の変形と応力に急変が確認され た。

この急変前後の 9 月 18 日と 9 月 21 日の山留め壁の変 形と曲げモーメントの分布を, 図一 5,6 に示した。

9 月 21 日の, 左側の山留壁（測点C）の変形は掘 削側に増加し，これに対応して，右側の対面する山留め 壁（測点 B）は背面側に押し戻されている。なお，この 原因は，以下に述べる同時期の異常降雨によるものであ る。

平成 3 年の 8 10月にかけて, 都内各地では, 例年に なく降雨日が多く，降雨量も異常といえる量であった。 都下清瀬市内の観測井戸では約 $6 \mathrm{~m}$ の地下水位の上昇 が確認されている。

図一 7 には，東京練馬地内の 8 10月の 3 力月間の月 間平均降雨量と平成 3 年におけるこの間の降雨量とを比 較して示した（気象庁の資料による）が，平成 3 年 8一 10 月の降雨量は, 例年の 3 ～倍となっている。また, 図一8には，本工事場における平成 3 年の 9 月 1 日から
10月 15 日までの日別の降雨量を示したが; 上記測点 C の山留め壁の挙動が急増した 9 月 19 日には，平年の平

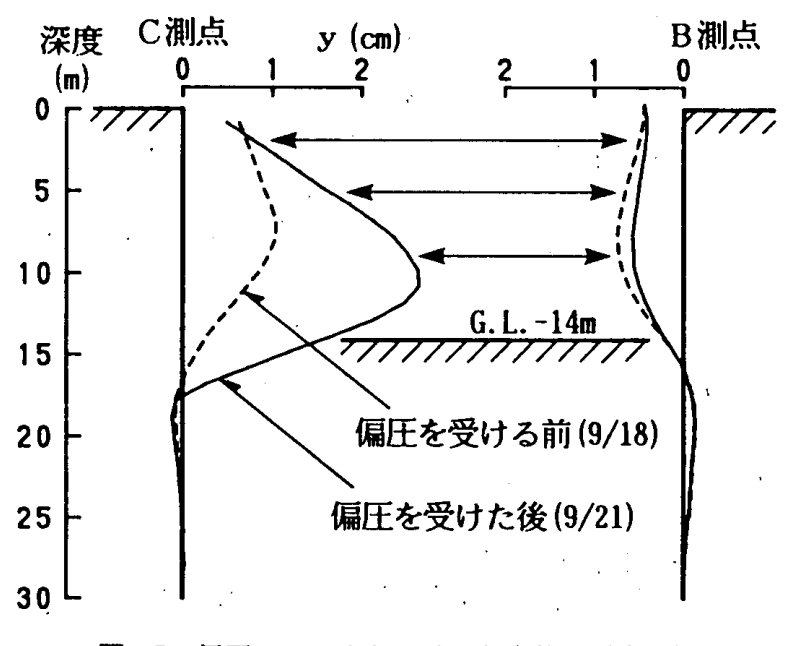

図一5偏生による山留め壁の急変状況（変形）

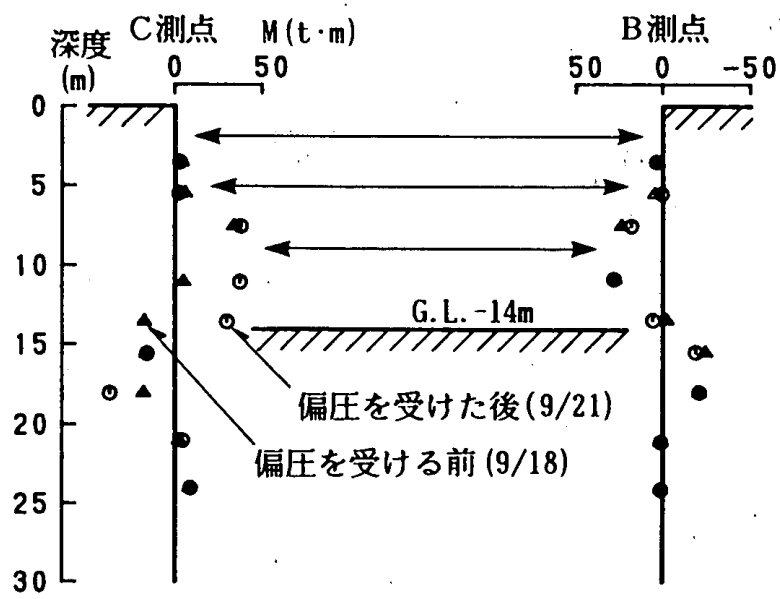

図一6 偏圧による山留め壁の急変状況（曲げモーメント）.

均月間雨量にほぼ等しい $210 \mathrm{~mm}$ という量を記録してい る。

この時点の事務所棟工区では約 $14.0 \mathrm{~m}$ までの 4 次根 切りがほぼ終了し，4 段切梁の架設準備に入っていた。・ これに対して，隣接する駐輪場棟工区はソイルセメシト 山留め壁の施工が完了し (平成 3 年 6 月); 地表面約 50 $\mathrm{cm}$ がすき取られている状態にあうた。このように，特 に, 舗装面が剝がされ山留め壁で仕切られた駐輪場棟工 区内では，8月中旬から 9 月の中旬にかけての多量の降 雨が逃げることなく，そのまま地中に集積されていたと 言える。特に，9月19日の $200 \mathrm{~mm}$ を越す雨量によう て同工区内の水圧は一気に増大したことが，十分予測さ れる。

図一9には，9月におけるAおよびB測点 $($ 図一2)で の水圧の経日変化を示した。

$A$ 測点は; JR 中央線に面している部分で，地表部が 鉄道路線の砕石であることから降雨の吸収率が良く, 各 深度の水圧には，9月13日２1 日にかけて顕著な増加 

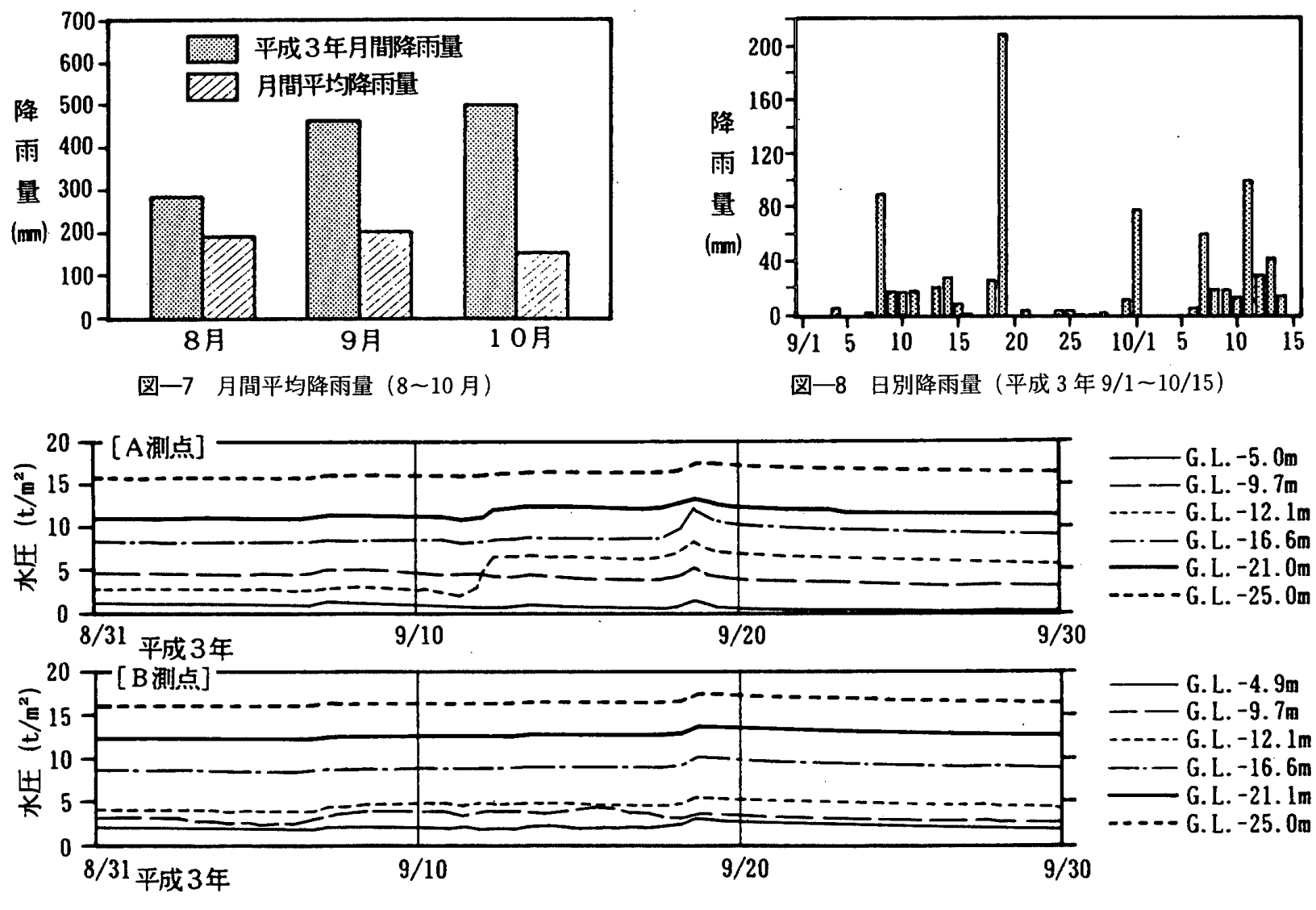

図一9水王の経日変化図

が認められる。また, 山留め壁の挙動が急変したC 測点 の対面に位置する B 測点では, 地表部が舗装されている ため降雨の吸収も悪く, 水王増加の傾向はA測点ほど顕 著ではない。

一方, 山留め壁の挙動が急変したC測点では, 山留め 壁に作用する駐輪場棟工区内の水生测定を行っていない が, 同工区内の水圧増加は, 周囲を止水性の良いソイル セメント山留め壁で仕切られていることから，上記 Aお よびB測点以上であったことが容易に推測される。

さらに，地下水位上昇の面からみると，9月13日一 。21 日におけるA测点, B测点での地下水位の上昇は約 $2 \mathrm{~m}$ (通常地下水位：約 G. L. - $3 \mathrm{~m}$ ) であった。そこで, これらを考慮して, 9 月 25 日に急拠, 駐輪場棟工区内 (C 測点の背後)に観測井戸を設け，地下水位を観測した。 その水位は, 当工事着手時の敷地内地下水位, 約 G. L. $-5 \mathrm{~m}$ に対し, 約 G. L. $-1 \mathrm{~m}$ にあり，集中降雨時には 少なくとも $4 \mathrm{~m}$ の上昇があったものと推測される。

図一10には, 雨水を比較的吸収しやすいA測点（事 務所棟工区）の水珐分布図を示した。

事務所棟工区の根切り開始直後の水生分布は， G. L. $-7.5 \mathrm{~m} \sim 9.5 \mathrm{~m}$ に存在する粘土層で不連続となる形態 を示している。これに対して，多量の雨量が供給された 9 月 21 日の時点では,この不連続な状態はみられず, その分布は, 地下水位面である G. L. $-3 \mathrm{~m}$ 位置からほ ぼ直線的な増加性状を示している。この状況から判断す

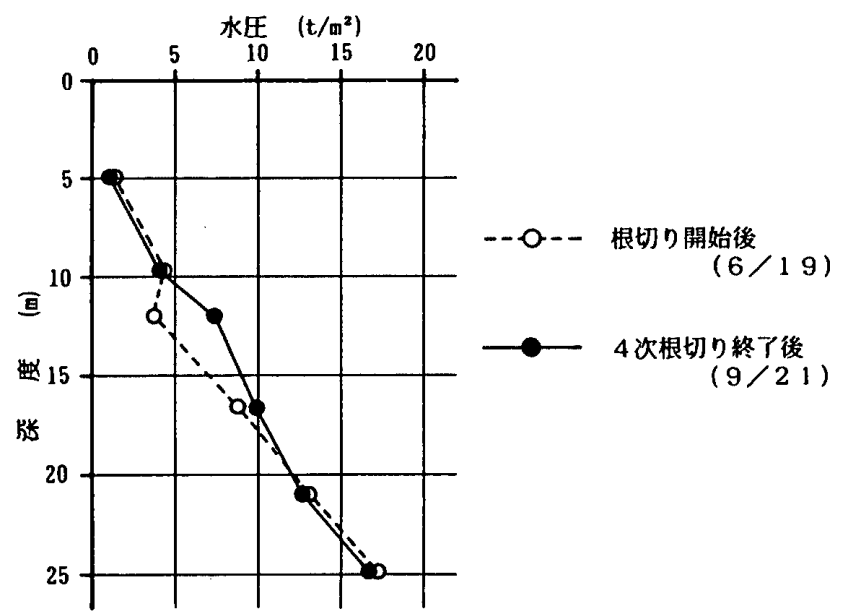

図一10 A測点における水圧分布の変化

ると, 雨水がより吸収しやすい状況下にあった駐輪場棟 工区内の水珐分布は, 先に述べた G. L. $-1 \mathrm{~m}$ 近傍より, 静水王の状態にあったものと推定される。

以上, 先に図一 5,6 に示したように，事務所棟工区之 駐輪場棟工区との境界部の RC 山留め壁（測点 C）の 変形および応力が，9月19日を境にして，急増した原 因としては，同時期における異常降雨によるものと判断 される。

\section{2 異常降雨による山留め壁の挙動}

図一11には，B，C測点（図一2）における，9月 19 日を境として急変した前後の実測データから求めた，そ 
の変形および曲げモーメントの増分量を示した。

前項で述べたごとく，駐輪場棟工区内に急増した水圧 が作用したと判断されるC測点では, 山留め壁の変形量 が最大約 $25 \mathrm{~mm}$ ，また曲げモーメントが約 $45 \mathrm{t} ・ \mathrm{~m}$ も増 大している。一方, 対面するB 測点の山留め壁では, C 測点の変形増大の影響を受け，全体的に背面側に押し戻 され，曲げモーメントも減少する傾向を示している。ま た，B測点の押し戻され量は，C測点の変形増加量に比 して，小さくなっているが，これはB測点の背面側の地 盤が良好な関東口ームであるため, その地盤反力が大き く寄与したためと判断される。

また, 上記の山留め壁の変形性状の変動に対応して, 㬰測の切梁軸力も 9 月 19 日を境に急増しており，その 3 段切梁の軸力は山留め壁の幅 $1 \mathrm{~m}$ 当たり $9.1 \mathrm{t}$ から $22.0 \mathrm{t}$ と約 $13 \mathrm{t}$ も増大した。 3 段切梁には $\mathrm{H}-400 \times 400$ $\times 13 \times 21$ を使用しており，その切梁ば权定数を算定す ると, 約 $1500 \mathrm{t} / \mathrm{m} / \mathrm{m}$ となる。そこで, このばね定数に 3 段切梁位置の両側の壁の相対変形増加量, 約 13.0 $\mathrm{mm}$ を乗ずると, 約 $20 \mathrm{t}$ となり，3段切梁軸力の実測増 加量をほぼ説明することができる。

図一12には，山留壁の挙動が急変した前後の, B, C測点の鉄筋応力の分布を示した。

$\mathrm{B}$ 測点の場合, 深さ方向各測点の引張側応力と王縮側 応力は，ほぼ同じ値を示し，またその值も $200 \mathrm{~kg} / \mathrm{cm}^{2}$

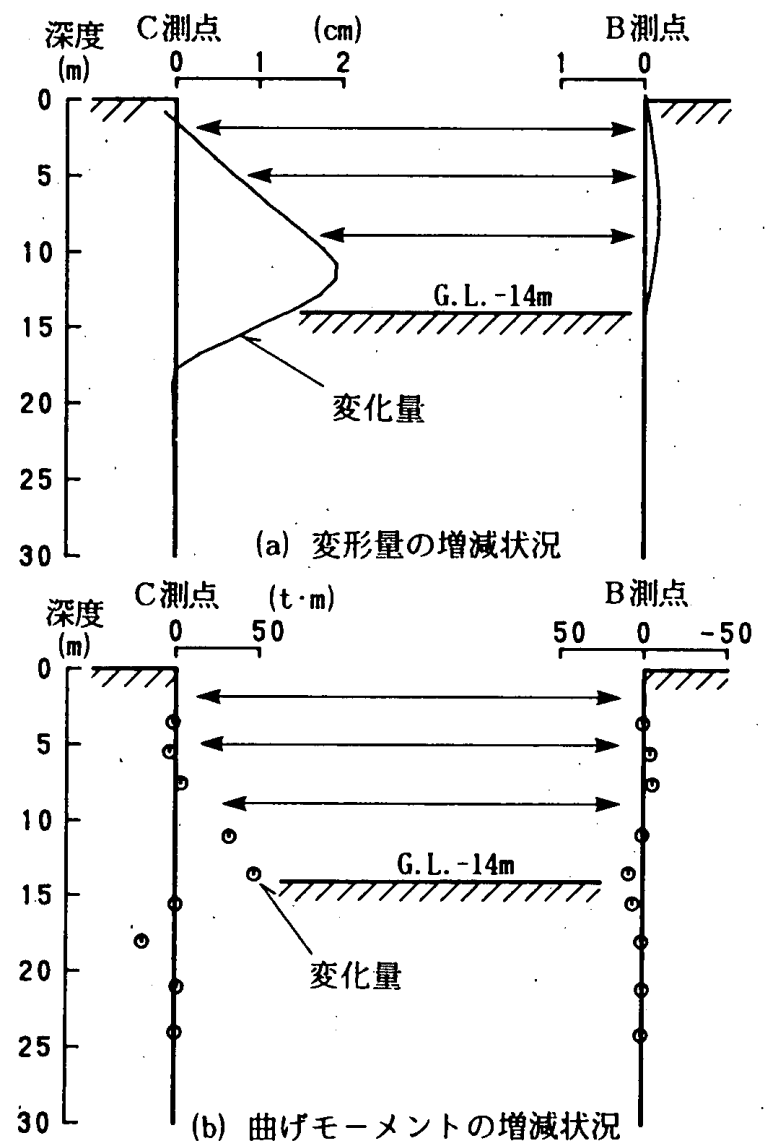

図一11 偏圧による山留め壁の変化量
以下となっている。これに対して，C測点では，深さ $11 \mathrm{~m}, 14 \mathrm{~m}$ および $18 \mathrm{~m}$ の 3 測点で引張側応力が急増し, 圧縮側応力を大きく上回っている。これより，この部分 での断面ではコンクリートに引張り亀裂が生じ, また曲 げ剛性も低下しているものと判断される。なおこれら の詳細な検討は, 後述する 5 章で行っている。

\section{3 増加水任に対する対策とその効果}

ここでは, 上記の水圧の急増による山留め壁の変形・ 応力増に対して, 当工事で対処した対策とその効果の概 要について述べる。

事務所棟工区の根切りは，上記集中降雨時には，最終 5 次根切りまで, 根切り深さ約 $3.8 \mathrm{~m}$ を残しており, 駐輪場棟工区との境界にある RC 山留め壁の状況を考 えると，そのままの状態で工事を進めるには問題があっ た。そこで，同山留め壁にさらに大きな影響を与えない よう対面するB測点側から根切りを行うとともに，この 間に駐輪場棟工区のほぼ中央部に, 直径 $400 \mathrm{~mm}$, 深さ $16 \mathrm{~m}$ のディープウェルを設置し, 駐輪場楝工区の地下 水位を G. L. $-6 \mathrm{~m}$ 前後まで下げることとした。ディー プウェルでの排水量は, 初期の段階で 14 - $15 \mathrm{~m}^{3} / \mathrm{hr}$, そ の後は 4 $5 \mathrm{~m}^{3} / \mathrm{hr}$ 程度であった。このディープウェル での排水は顕著な効果を発揮し, 図一13に示すとおり, $C$ 測点での変形と応力は集中降雨前の 9 月 18 日時点の 状態に復帰した。一方, 対面するB測点では, 背面側に 押し戻されていた状態が解放され, 再度根切り場内側に 変形が最大約 $12 \mathrm{~mm}$ 移行している。

これらの結果より, 両工区境界部の山留め壁の変形は 上記集中降雨による急激な水圧の増大によって生じたこ とが再確認された。

以上, 当工事のようにそれぞれを止水性山留め壁で仕 切った二つの工区を時期を変えて根切りする場合, その 境界部の山留め壁には過剩な水圧が作用することがあ

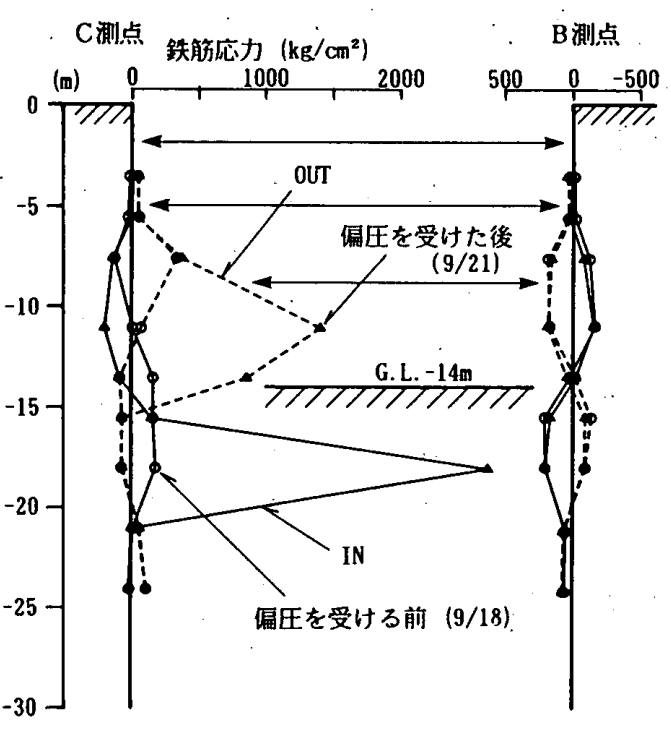

図一12 偏圧による山留め壁鉄筋応力の変化 


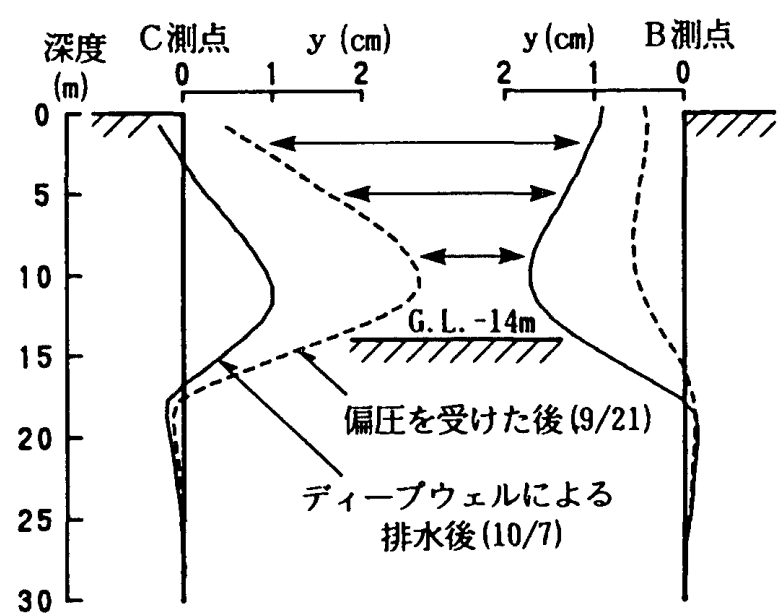

(a) 变形

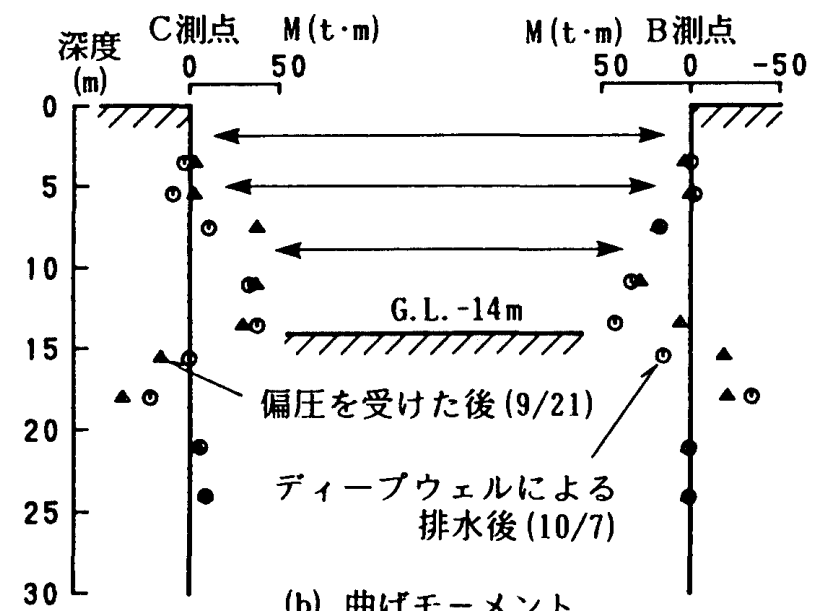

(b) 曲げモーメント

图一13 ディープウェルでの排水による効果

り，山留め架構としては偏圧办が㗢くことにもなるので, 山留めの設計および施工に当たっては，これらの事項も 十分検討する必要性が認められる。

\section{4. 対面する山留め壁の一体解析方法}

本論で提示する実用的解析方法では，一般の山留めの 設計に用いられている梁・ばねモデル゙を適用した Es-y 法 ${ }^{21.3)}$ を発展させ，切梁軸力を介して対面する山留 めの挙動を一体解析している。また，本解析方法(4) 7)の 仮定条件および特徴は以下のごとくである。

(1) 地盤および山留め壁を，地盤状態および側圧等を考 慮して，層分割する

(2) 各層の地盤反力は, 変位の関数として与え, trilinear curve に置換する

(3) 各層の山留め壁の曲げ剛性は，山留め壁に発生する 曲げモーメントの関数として与える

(4) 対面する山留め壁間に架設される切梁は, ばねに置 換する

(5) 山留め架構に作用する各層の側圧は，1 次関数で与 える

\section{1 基本方程式とその解法}

図一14に示した解析モデルにおいて，各層の基本方
程式を，根切り底以浅では（1）式で, 同以深では（2） 式で与えている。なお，根切り底以浅でも，山留め壁が 背面側に押し戻され，背面地盤の反力が作用する場合に は，（2）式を適用している。なお, 同基本方程式中, 添字 $L$ は左壁を示しているが, 右壁の基本方程式も, 両式において， $L$ を $R$ に置き換え与えられる。 <根切り底以浅>

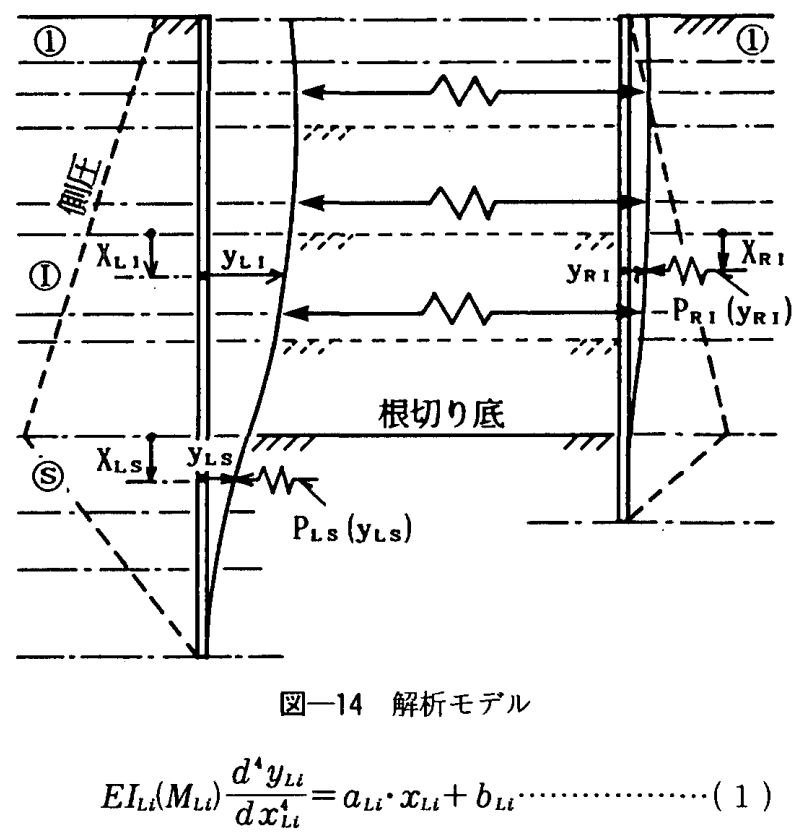

<根切り底以深>

$$
E I_{L S}\left(M_{L s}\right) \frac{d^{4} y_{L s}}{d x_{L S}^{4}}+P_{L s}\left(y_{L s}\right)=a_{L s} \cdot x_{L s}+b_{L s} \cdots
$$

ここで, $x$ : 層上端からの梁さ, $y: x$ における変位, $E I(M)$ : 山留め壁の曲げ粫性, $M$ : 層上端での曲げモ一 メント, $P(y)$ : 地盤反力, $a \cdot x+b$ : 側圧である。

また，（2）式中の地盤反力 $P(y)$ は, 後に示すが, 解析時には, tri-linear curve として計算に導入している。 したがって，(2) 式の $P(y)$ は下式に変換できる。

$$
P_{L s}\left(y_{L s}\right)=p_{L s} \cdot y_{L s}+q_{L s}
$$

ここで, $p, q$ : 任意定数である。

（3）式を（2）式に代入し，各層内では $E I$ および $p, q$ を一定とすると，(1) 式および（2）式の一般解 は, 以下のように求められる。

<掘削底面以浅 $: i$ 層〉

$$
\begin{aligned}
y_{L i}= & R 1_{L i} x_{L i}^{5}+R 2_{L i} x_{L i}^{4}+R 3_{L i} x_{L i}^{3}+R 4_{L i} x_{L i}^{2} \\
& +R 5_{L i} x_{L i}+R 6_{L i} \cdots \cdots \cdots \cdots \cdots \cdots \cdots \cdots \cdots \cdots \cdots \cdots \cdots \cdots \cdots
\end{aligned}
$$

<掘削底面以深 $: s$ 層>

$$
\begin{aligned}
& y_{L S}=\exp \left(\beta_{L S} x_{L S}\right)\left(A_{L S} \cos \beta_{L S} x_{L s}+B_{L S} \sin \beta_{L S} x_{L S}\right) \\
& +\exp \left(-\beta_{L S} x_{L S}\right)\left(C_{L S} \cos \beta_{L S} x_{L S}\right. \\
& \left.+D_{L s} \sin \beta_{L s} x_{L s}\right)+\left(E_{L s} x_{L s}+F_{L S}\right) \\
& \beta_{L s}=\sqrt[4]{\frac{p_{L s}\left(y_{L s}\right)}{4 E I_{L s}\left(M_{L s}\right)}}
\end{aligned}
$$

上式の, 任意定数, $R 1 \sim R 6$ および $A \sim F$ は, 以下 
の条件より決定する。

(1) 山留め壁の頭部および先端での境界条件

(2) 各層境界における変位, 変形角, 曲げモーメントお よびせん断力の連続条件

(3) 対面する山留め壁の挙動を連動させる切梁位置での せん断力の連続条件

上記(3)の切梁位置でのせん断力の連続条件は, 以下の ように与えられる(図一15)。

$j$ 次根切り時の切梁軸力 $\left(N_{j}\right)$ は, a) 前根切り段階の 切梁軸力 $\left(N_{j-1}\right)$ および b) 対面する両側の壁の切梁位置

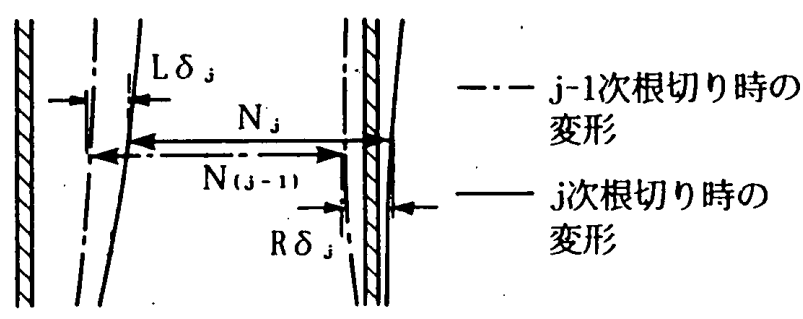

図一15 切梁位置でのせん断力の連続条件

での前段階からの変位増分による切梁軸力の増加量に よって，下式のごとく計算される。

$$
N_{j}=N_{j-1}+K\left({ }_{L} \delta_{j}+{ }_{R} \delta_{j}\right) \cdots
$$

ここで, $K$ は切梁のばね定数，また， ${ }_{L} \delta_{j},{ }_{R} \delta_{j}$ は左側 および右側の切梁位置における, $(j-1)$ 次根切り時から $j$ 次根切り時に移行したときの山留め壁の変位の増加量 である。

上記の切梁軸力より，左右の山留壁の切梁位置にお けるせん断力の連続条件は（8) 式で与えられる。

$$
{ }_{L} Q_{j l}={ }_{L} Q_{j u}+N_{j}, \quad{ }_{R} Q_{j l}={ }_{R} Q_{j u}+N_{j}
$$

ここで， $Q_{\jmath l}, Q_{j u}$ は，切梁位置の下部および上部での せん断力である。

上記の解法では，地盤反力および曲げ剛性に非線形性 状を導入しているため, 解が一義的に求められない。そ こで, 実際の数値計算では, 各層において, 仮定した地 盤反力 $(p)$ と計算変形 $(y)$ が，また仮定した曲げ風性 $(E I)$ と計算曲げモーメント $(M)$ が，解析条件として与 えられた $p-y$ および $E I-M$ の関係を満足するまで, 二 重の収れん計算を行い, 解を求めている。

\section{2 地盤反力}

本研究における (2) 式の地盤反力項には, 多数の杭 の水平交番載荷試験により求めた，下記の非線形性状を 導入している。なお，この非線形性状は地盤種別などに 大きく影響を受けないことが確認されている ${ }^{81-10)}$ 。

杭の水平載荷試験結果より統計的に求めた，処女載荷 時の水平地盤反力係数 $\left(K_{H}\right)$ の非線形性状は $(9)$ 式, また除荷時および再載荷時（以下，履歷荷重時）の折り 返し点の座標を原点とした同性状は（10）式で評価され る。両式の $k_{H 1}$ は, 変位 $y=1.0 \mathrm{~cm}$ 時の $k_{H}$ である。
〈処女荷重時 $>$

$$
\frac{K_{H}(y)}{K_{H 1}}=\frac{1}{\left(0.35 \times y^{2}+0.6 \times y+0.05\right)^{0.5}}
$$

〈履歴荷重時 $>$

$$
\frac{K_{H}(y)}{K_{H 1}}=\frac{1}{\left\{0.35 \times(y / 2)^{2}+0.6 \times(y / 2)+\left.0.05\right|^{0.5}\right.}
$$

図一16(a)には，(9)，(10) 式より求めた, $p(y) /$ $E_{s 1}-y$ 曲線 $\left(E_{s 1}=k_{H 1} \times B, B\right.$ :山留め壁の幅 $)$ を破線 で示した。この曲線を実線のようう tri-linear 曲線に置 換し，根切り底以深の地盤反力に導入している。

一方, 根切り底以浅部の地盤反力は, その変形が過去 の掘削側の最大変形以上になると発揮されないため, 図 -16(a) の下半分の曲線，すなわち同図 (b) の実線を 導入している。

\section{3 山留め壁の断面性能}

（1）および（2）式の曲げ剛性 $(E I)$ には，抵抗モ一

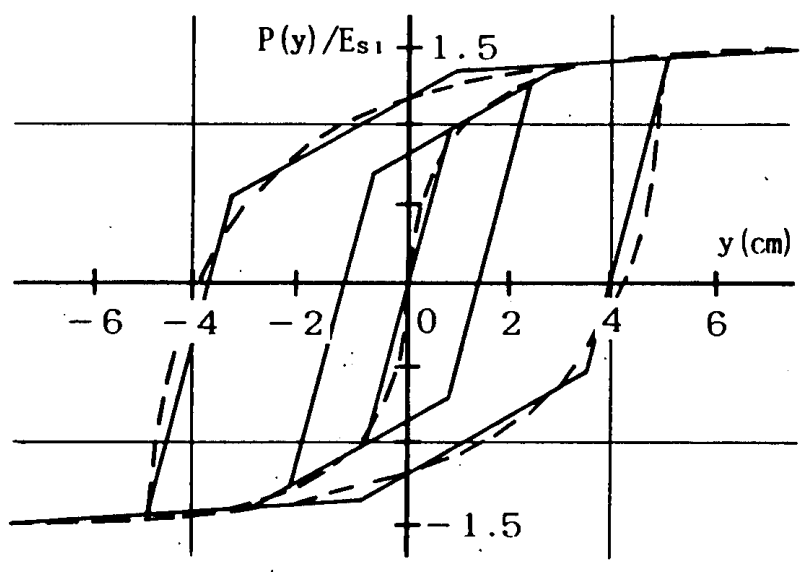

a ）根切り底以浅

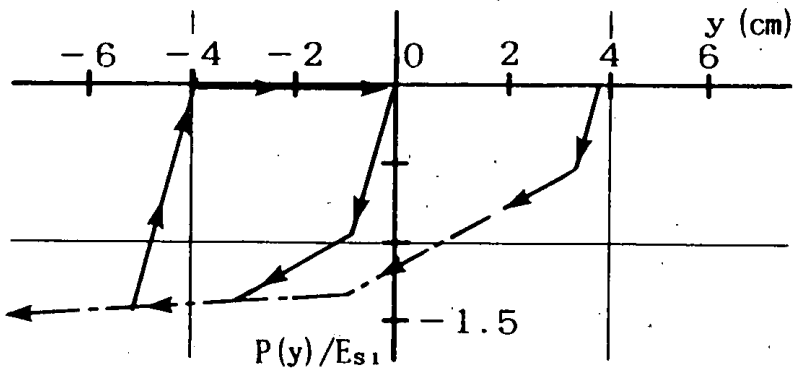

b ) 根切り底以深

図-16 $P(y) / E_{s 1}-y$ の関係

メント $(M)$ に応じた值を導入しているため，その $E I-M$ 関係を解析的に求めておく必要がある。

以下には，次項で検討する $\mathrm{RC}$ 山留め壁の場合を例 に取り，本論での $E I-M$ 関係の解析方法 ${ }^{3)}{ }^{11}$ について 示す。

また，この解析条件は以下のとおりであるが，この解 析の特徴としては, 特に, コンクリートの引張強度（圧 
縮強度の 0.15 倍 $)^{12\}}$ を評価しているため, $E I-M$ 曲線 が連続の曲線として求められることである。

\section{〈解析条件〉}

(1) 山留め壁断面におけるひずみ分布：平面保持とする

(2) コンクリート, 鉄筋の応カーひずみ曲線：完全弾塑 性

(3) コンクリートの引張強度 : ${ }_{c} F_{c}$, 同引張強度 $:{ }_{c} F_{t}=$ $0.15 \cdot{ }_{c} F_{c}$

(4) 鉄筋の圧縮および引張強度 : ${ }_{c} f_{c}={ }_{c} f_{t}$

(5) 山留め壁断面の曲げ剛性 : $E I=M / \phi,\{M:$ 抵抗 モーメント, $\varnothing:$ :曲率

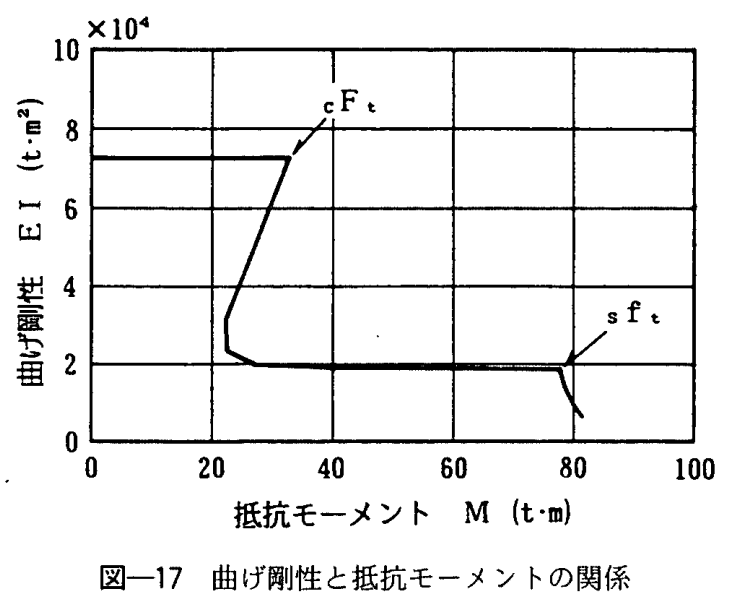

図一17には；次章で解析している，根切り工事 (2 章) に採用された $\mathrm{RC}$ 山留め壁断面の，計算により求めた $E I-M$ 関係を示した。なお, 山留め壁の諸元については, 次章に示す。

曲げ剛性 $(E I)$ は, コンクリートに引張亀裂 $\left({ }_{c} F_{t}\right)$ が発 生すると，大きく低下し，鉄筋の引張降伏 $\left({ }_{s} f_{t}\right)$ までは ほぼ一定值を維持する。また，抵抗モーメント $(M)$ は,
同亀裂発生に伴い，一時的に減少するが，それ以後鉄筋 の引張降伏までは耐力が増加し，また，最終曲げ而力は ほぼ鉄筋の引張降伏時の值で決定される。

このように，コンクリートに引張亀裂が発生すると， 曲げ剛性は大きく低下し，この低下が山留め壁の変形を 增大させると言える。

\section{5. 偏圧作用時の対面する山留め架構の一体解析}

本章では，先の 2 章で示した実際に施工された山留め 架構 (図一18) を対象とし, 特に異常降雨による水圧 (偏 王）作用時の同山留め架構の挙動を, 前章の解析方法を 用いて解析し，検討した。

以下に，解析を行った山留め壁の緒元および解析条件 を示す。

(1) 山留め壁（連続地中壁工法による $\mathrm{RC}$ 造）

壁厚 $: 70 \mathrm{~cm}$, 壁長 (施工深さ) $: 31 \mathrm{~m}$,

鉄筋：背面側, D22-@28cm,D19-@28cm, 掘削側：D29-@14 cm

(2) 切梁寸法

1 段切梁: $\mathrm{H}-350 \cdot 350 \cdot 12 \cdot 19(\mathrm{~mm})$

2,3 段切梁 : H-400 $400 \cdot 13 \cdot 21(\mathrm{~mm})$

(3) プレロード導入量

1 段切梁: $3.57 \mathrm{t} / \mathrm{m}, 2,3$ 段切梁 : $7.14 \mathrm{t} / \mathrm{m}$

(4) 材料強度

$\begin{aligned} \text { コンクリート: } & \text { 圧縮強度 }{ }_{c} F_{c}=240 \mathrm{~kg} / \mathrm{cm}^{2} \\ & \text { 引張強度 }{ }_{c} F_{t}=36 \mathrm{~kg} / \mathrm{cm}^{2} \\ & \text { ヤング率 「建築学会鉄筋コンク } \\ & \text { リート構造計算規準・同解説」 }\rfloor^{13)}\end{aligned}$

鉄筋：圧縮, 引張強度 ${ }_{c} f_{\mathrm{c}}={ }_{c} f_{t}=3500 \mathrm{~kg} / \mathrm{cm}^{2}$ ヤング率 $E=2.1 \cdot 10^{6} \mathrm{~kg} / \mathrm{cm}^{2}$

(5) 各層の曲げ剛性 $(E I)$ と曲げモーメント $(M)$ の関係
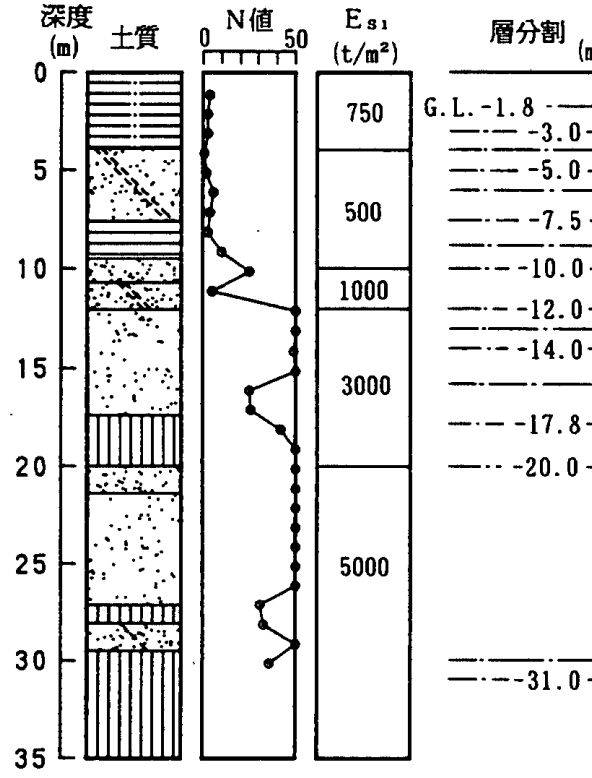

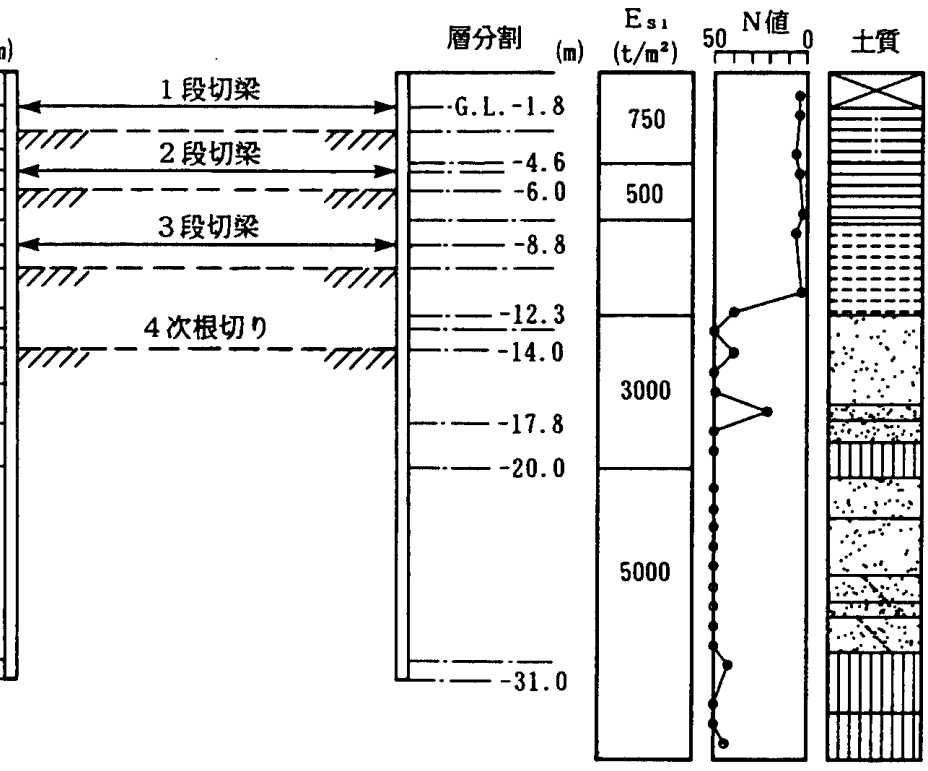

図一18 解析上での層分割 

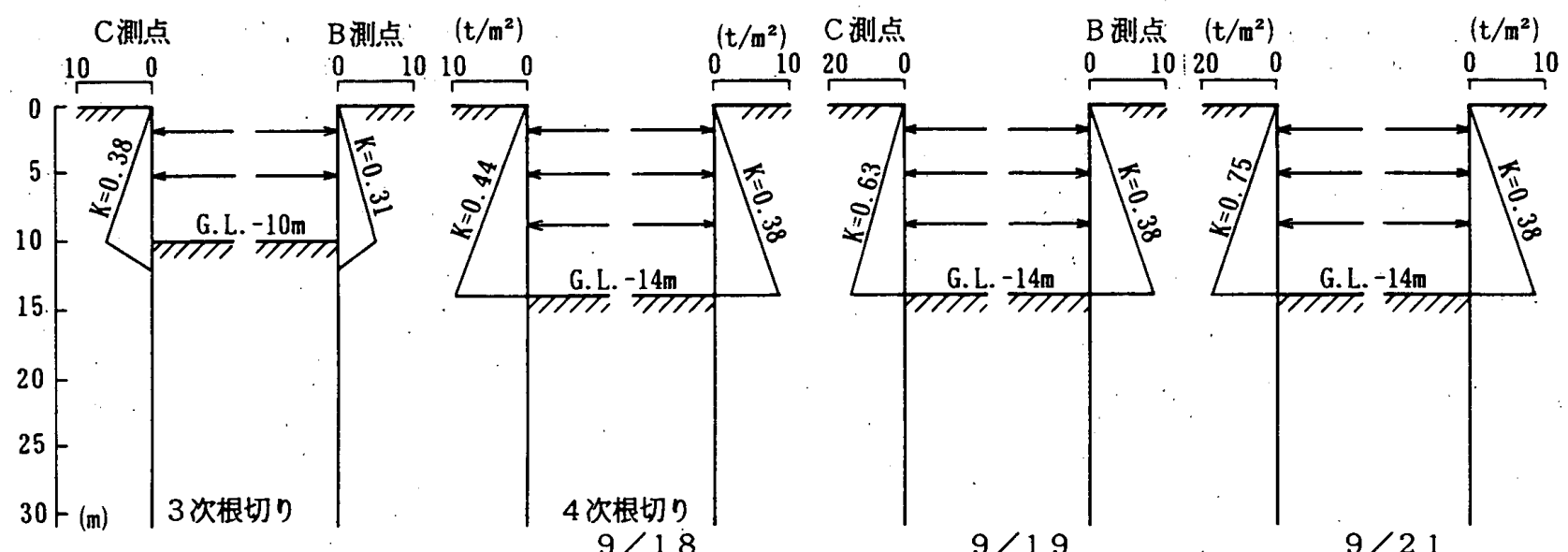

$9 / 18$

$9 / 19$

$9 / 21$

図一19 計算で採用した側圧分布

:図-17

(6) 各層の $y=1 \mathrm{~cm}$ 時の地盤の変形係数 $\left(E_{s 1}\right)$ : 図一 18

(7) 山留め壁の頭部および先端条件：自由

また，解析における側圧は，図一19のように定めた。 ここで，B測点側は実測側圧であり，C測点側での異常 降雨以後の側圧は, 前述のように測定していないため, その直後（第 4 次根切り）に測定された地下水位 G. L. $-1.0 \mathrm{~m}$ から静水圧が作用していると仮定して設定し
た。

図一20には， 3 次根切り段階および異常降雨以後 $(9$ 月 19 日，21日）の，計算值 (実線) の山留め壁の変形 および曲げモーメント分布を実測值（○印）と対比して 示した。なお, 同図の 4 次根切り時以降の曲線には, 参 考のため, 山留め壁の曲げ剛性の評価にコンクリートの 引張亀裂等を無視した場合 (弾性, 破線) の值も併記し た。

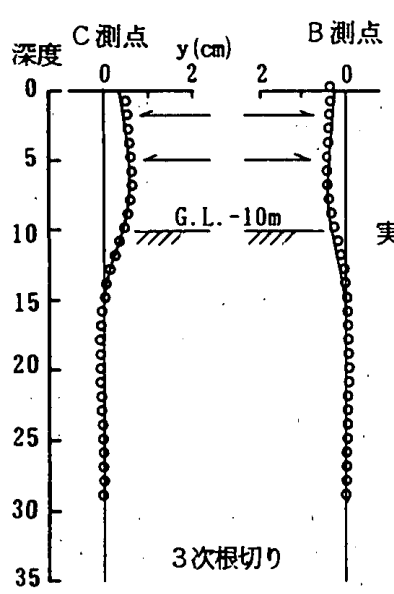

(m)
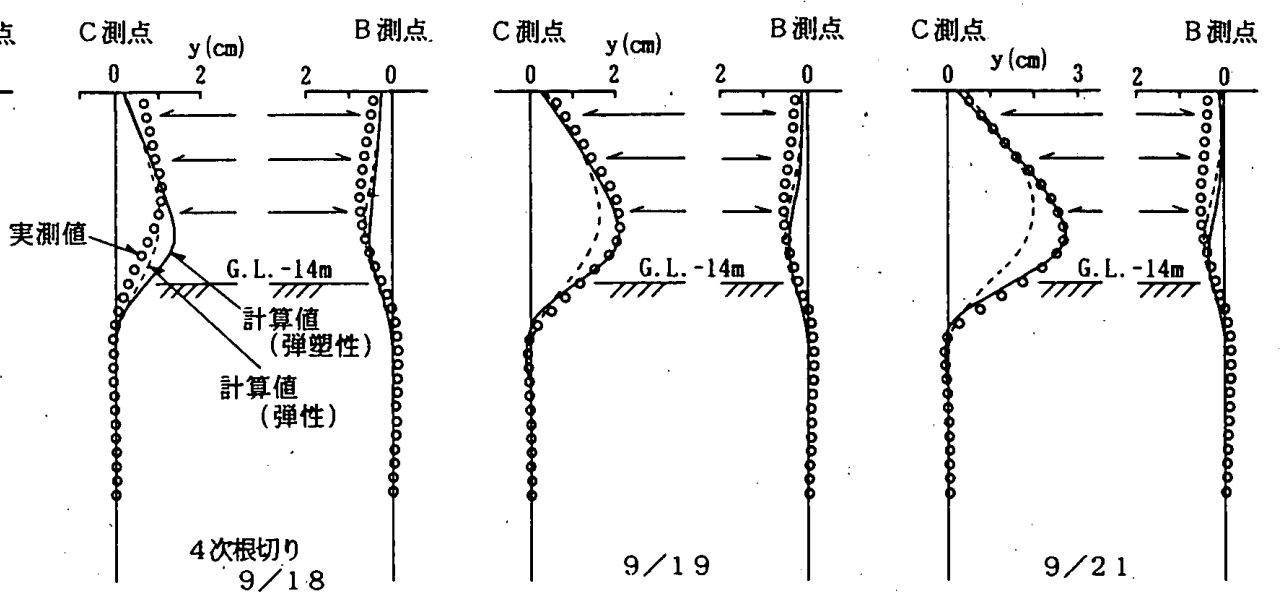

(a) 変 形
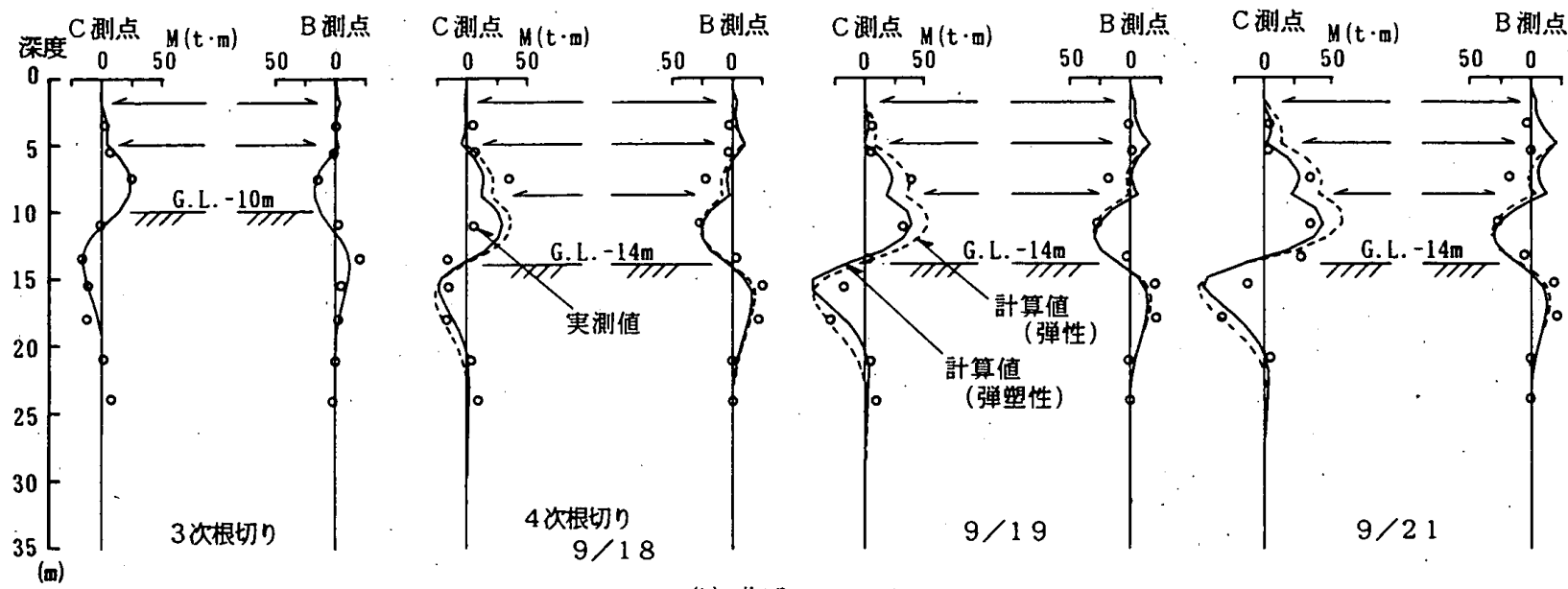

(b) 曲げモーメント 


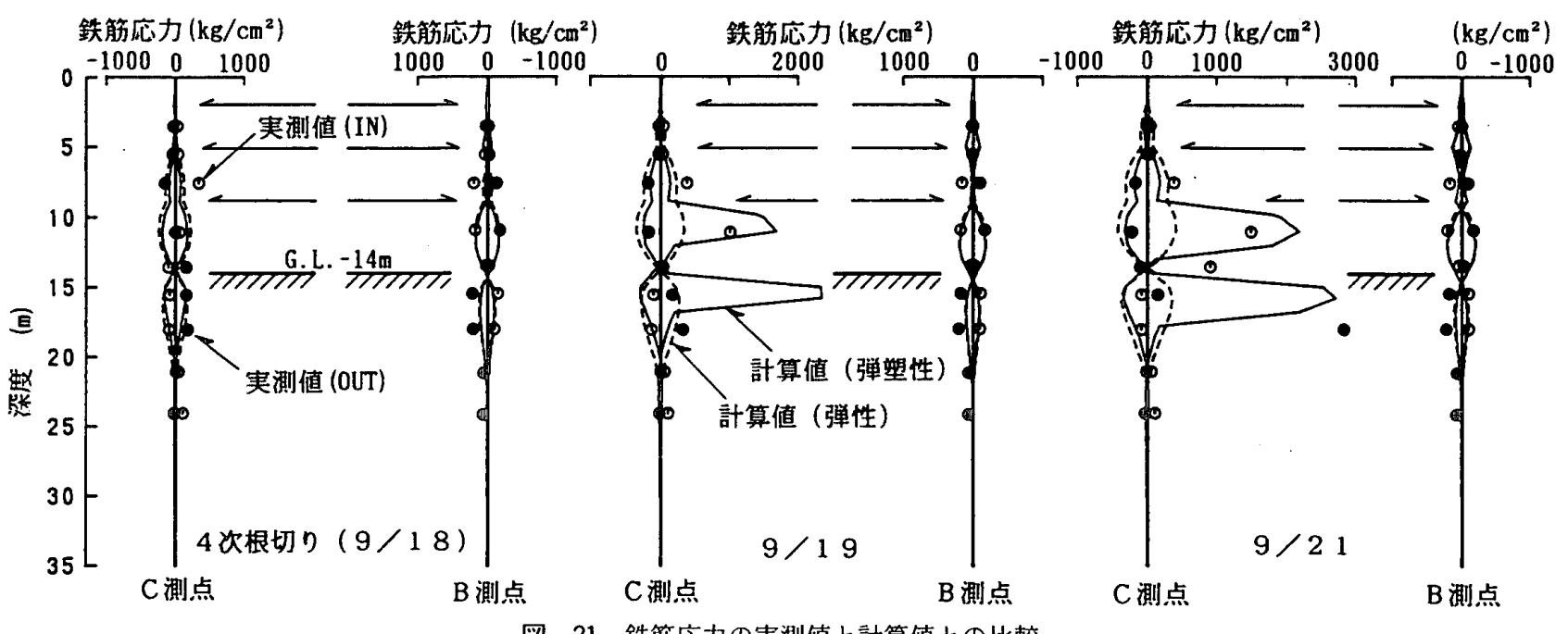

図一21 鉄筋応力の実測値と計算値との比較

3 次根切り時の場合, 計算值の変形は, 両側の壁がほ ぼ同等に掘削側に変形している実測の性状をよく説明し ている。これらの性状は，曲げモーメント分布において も認められる。

これに対して，9月 18 日の 4 次根切り完了時には, $C$ 測点側の実測変形が $\mathrm{B}$ 測点側に比して大きく現れてお り，この時点で既に異常降雨の影響が認められる。さら に, 偏圧（水珐）が増加したと推察された 9 月 19 日お よび 21 日の実測変形は, 曲げモーメント分布と同様に, C測点側では増大し，また，B測点側ではわずかではあ るが押し戻されている。

以上の害測性状は，弾性解よりも，山留め壁の曲げ剛 性に弾塑性性状（図一20）を導入した計算值（弾塑性） が，よりよく一致している。

そこで, 図一21には，4 次根切り以後の，実测鉄筋応 力分布と上記計算値 (弾塑性解) を対比して示した。な お, 同図中の IN は掘削側, OUT は背面側の值である。

C測点側の, 特に 9 月 21 日の鉄筋の引張応力の実测 值は, G. L. $-11 \mathrm{~m}$ およびー14 $\mathrm{m}$ 近傍で $1000 \mathrm{~kg} / \mathrm{cm}^{2}$ 以上に達している。これらの值は, $E I-M$ 関係を導入 した計算値とよく一致しており，この結果，これらの部 分ではコンクリートに引張亀裂が発生したといえる。

以上の解析結果より, 異常降雨時の山留め壁の変形の 増加は, 偏圧 (水圧) の増加に加えて, 曲げ剛性の低下 にも関係していることが判断される。

\section{6. 結 語}

山留め架構に作用する偏圧は, 一般的に, 傾斜地や地 表面に高低差がある場合に対象となるが，本論での事例 より, 異常降雨時においても, その水位上昇に伴う水圧 が偏圧として山留め架構に作用することが明らかとなっ た。この結果, 山留め壁には過大な変形や応力が発生す ることも判明した。

さらに, 上記の山留め架構の挙動は, 本論で提示した,
対面する山留め壁の一体解析方法でよく説明された。ま た，これらの解析には，非線形性状を有する背面側の地 盤反力をも考慮するとともに，山留め壁の曲げ㓮性の弾 塑性性状を十分評価し，導入する必要性も認められた。

\section{参考文献}

1）山肩邦男, 吉田洋次, 秋野矩之：掘削工事における切バ リ土留め機構の理論的考察, 土と基礎, Vol. 17, No. 9, pp. 33 45, 昭和 41 年 9 月

2）古藤田喜久雄, 風間 了, 丸山今朝美：山どめ壁および くいの水平抵抗に関する研究 (その 1 3), 第 10 回土質 工学研究発表会, 発表講演集, pp. 867 878, 昭和 50 年 6 月

3）古藤田喜久雄, 風間 了, 宮原茂美: 土の非線形性状と コンクリートのキレツによる壁の剛性低下を考虑した $\mathrm{RC}$ 山どめ解析 (その 1 , その 2), 日本建築学会大会学 術講演梗概集，pp. 2055 2058, 昭和 53 年 9 月

4）古藤田喜久雄, 風間 了, 秋葉堅一, 小川 洋: 偏土压 が作用する山留めの解析例について, 第 20 回土質工学研 究発表会, 発表講演集, pp. 1227 1230, 昭和 60 年 6 月

5）古藤田喜久雄, 風間 了, 小川 洋, 加藤千博, 鶴田賢 二：偏土王が作用する山留めの解析例について (その 2), 第 21 回土質工学研究発表会, 発表講演集, pp. 1341 1342 , 昭和 61 年 6 月

6) 古藤田喜久雄, 風間 了, 加藤千博, 鶴田賢二：偏土圧 が作用する山留めの挙動 (その1, その2), 日本建築学 会大会学術講演梗概集, pp. 1305 1308, 昭和 61 年 8 月

7）古藤田喜久雄, 風間 了, 加藤千博：対面する山留壁の 同時解析方法, 日本建築学会大会学術講演梗概集, pp. $1187 \sim 1188$, 昭和 62 年 10 月

8) 古藤田喜久雄, 風間 了, 丸山今朝美: 地盤の変形係数 $E_{s}$ に関する実験的研究, 日本建築学会大会学術講演梗概 集, pp. 1711 1712, 昭和 51 年 10 月

9）竹内盛雄, 古藤田喜久雄, 風間 了, 石原和男 : くい基 礎の水平方向復元力特性に関する研究 (その1), 日本建 築学会大会学術講演梗概集, pp. 1721 1722, 昭和 54 年 9 月

10）竹内盛雄, 古藤田喜久雄, 風間 了: くい基礎の水平方 向復元力特性に関する研究 (その 2 . 繰返し荷重時の水 
平方向地盤反力), 日本建築学会大会学術講演梗概集, pp. 2075 2076, 昭和 55 年 9 月

11）古藤田喜久雄, 風間 了, 中村義明：くい材の塑性性状 を加味した解析法（その 1 , その 2 ), 第 12 回土質工学研 究発表会, 発表講演集, pp. 801 808, 昭和 52 年 5 月

12）小坂義夫，森田司朗：鉄筋コンクリート構造，丸善，昭
和 50 年

13）日本建築学会：鉄筋コンクリート構造計算規準・同解説 昭和 46 年, 第 5 版, 昭和 63 年

(1992 年 3 月 9 日原稿受理, 1992 年 6 月 8 日採用決定) 